\title{
Examination of islets in the pancreas biopsy specimens from newly diagnosed Type 1 (insulin-dependent) diabetic patients
}

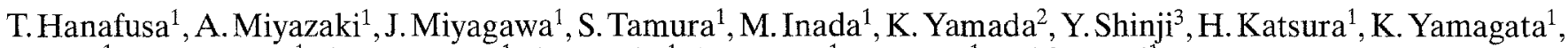 \\ N. Itoh ${ }^{1}$, H. Asakawa ${ }^{1}$, C. Nakagawa ${ }^{1}$, A. Otsuka ${ }^{1}$, S. Kawata ${ }^{1}$, N. Kono ${ }^{1}$ and S. Tarui ${ }^{1}$ \\ ${ }^{1}$ The Second Department of Internal Medicine, Osaka University Medical School, Osaka, \\ ${ }^{2}$ Department of Medicine, Division of Endocrinology and Metabolism, Kurume University School of Medicine, Kurume, and \\ ${ }^{3}$ Nishinomiya Prefectural Hospital, Nishinomiya, Hyogo, Japan
}

\begin{abstract}
Summary. We attempted to examine the immunopathological change of the pancreatic islets of newly diagnosed Type 1 (insulin-dependent) diabetic patients and thereby to obtain useful information for the therapy of the patients. For this purpose, pancreas biopsy under laparoscopy was performed 2-4 months after the onset of Type 1 diabetes in seven newly diagnosed patients. All biopsies were performed safely without any complications. Immunohistochemical examination of the biopsy specimens revealed a marked decrease of insulin-containing cells, preservation of glucagon-containing cells, and various degrees of expression of MHC class I and class II antigens in islet cells and in endothelial cells within and around the islets. Signs of active autoimmune phenome-
\end{abstract}

na, e.g. lymphocytic infiltration or immunoglobulin deposition in islets, were not detected in any of these patients by light microscopical evaluation. We conclude that pancreas biopsy under laparoscopy has shown various immunological changes in the islets of newly diagnosed Type 1 diabetic patients. Pancreas biopsy, however, may not be suitable under the present protocol for the selection of patients for immunotherapy because of problems including sampling errors.

Key words: Type 1 (insulin-dependent) diabetes mellitus, pathology, pathogenesis, diagnosis, pancreas biopsy, laparoscopy, immunohistochemistry, MHC class I antigen, MHC class II antigen, immunotherapy.
Accumulating evidence strongly suggests that Type 1 (insulin-dependent) diabetes mellitus is primarily of an autoimmune origin $[1,2]$. Several studies have reported on autopsy samples on the pathology of islets of Type 1 diabetic patients [3-7]. However, little is known concerning immunohistochemical features of islets of such patients who recovered from acute ketoacidosis.

In our department, we have accumulated experience of abdominal organ biopsy under laparoscopy in more than 6000 patients with liver diseases and related disorders. This experience enabled us to establish a safe method of pancreas biopsy. Pancreas biopsy under laparoscopy is not a new technique and has been performed for the diagnosis of pancreas tumour, pancreatitis and other pancreatic diseases $[8,9]$. Application of this technique to patients with newly diagnosed Type 1 diabetes could possibly reveal more direct evidence than any other tests available for pathogenic mechanisms involved in beta-cell destruction. In situ characterization of various phenomena occurring in the islets of newly diagnosed Type 1 diabetic patients would also provide important insights into specific therapies for the patients in the early stage of this disease.

\section{Subjects and methods}

The study was carried out according to the Declaration of Helsinki and approved by the ethical committee of Osaka University Medical School. The patients were fully informed of the study's inherent risks and foreseeable benefits to themselves, and written informed consent was given by the patients.

\section{Patients}

Seven patients (four males and three females) with newly diagnosed Type 1 diabetes were examined. The details of the patients are shown in Table 1. The mean ( \pm SD) age was 32.6 \pm 9.5 (range 24-49). They all showed acute progression of symptoms such as polyuria, polydipsia, and body weight loss of more than $5 \%$. The diagnosis of Type 1 diabetes was based on the presence of hyperglycaemia, ketonuria in addition to the above symptoms. Insulin therapy and physiological saline $(0.9 \% \mathrm{NaCl})$ infusion was started as soon as the diagnosis was confirmed. Patient no. 3 was referred to our clinic during the remission period 5 months after the first onset of diabetes. At the time of her first onset of diabetes, she was treated in another hospital for 3 weeks with insulin and then became normoglycaemic without insulin. However, her fasting plasma glucose level had started to increase when she came to our clinic.

At the time of diagnosis, all the patients except nos. 5 and 7 were positive for cytoplasmic islet cell antibodies (ICA) assessed by indi- 

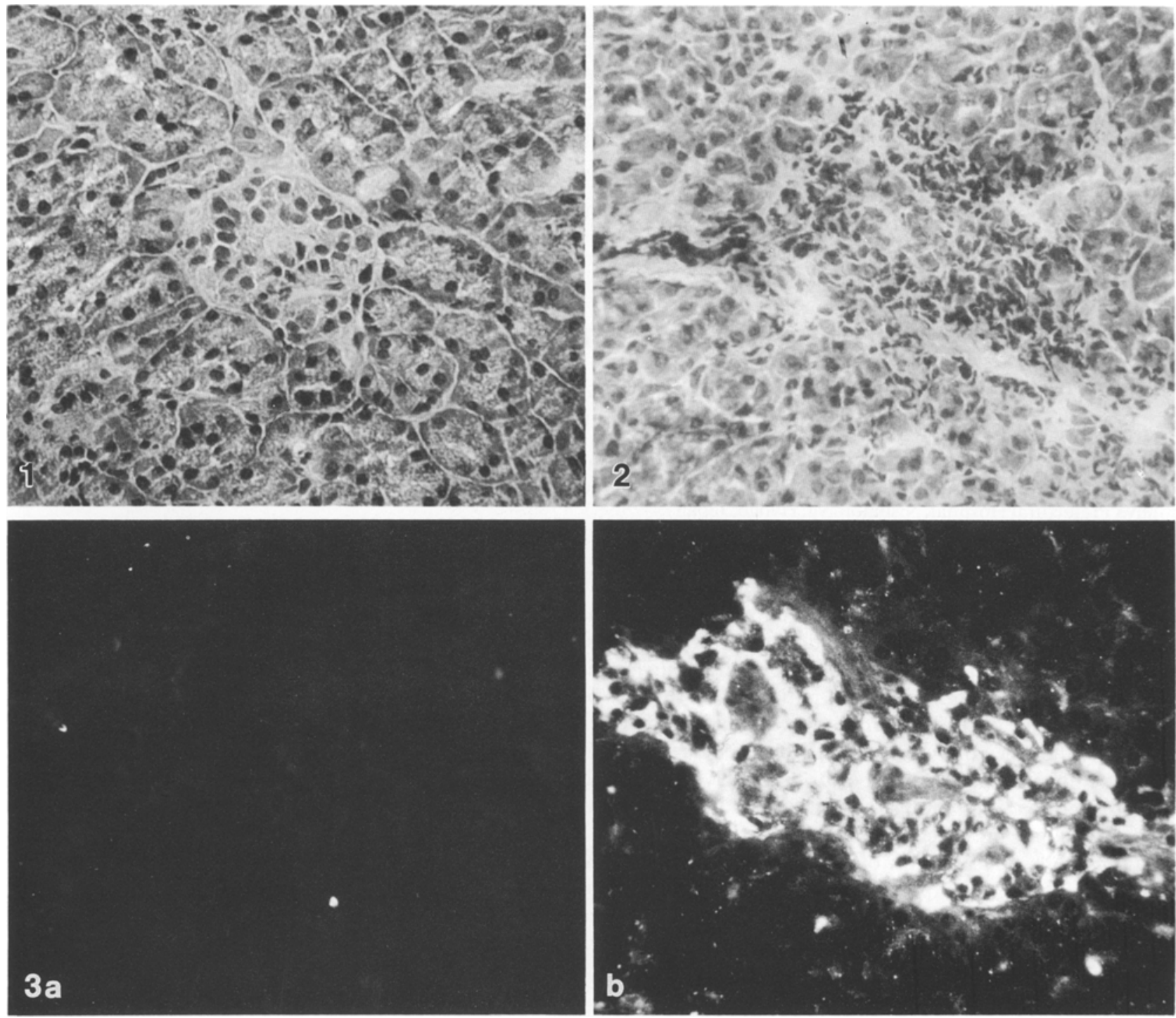

Fig. 1. Frozen section of pancreas biopsy specimen from patient no. 4, stained with haematoxylin and eosin. A small islet is seen in the centre of the section. This islet is composed of a small number of islet cells, whose arrangement appears to be distorted. These features were seen in most islets of the specimens from all patients studied. The exocrine pancreatic tissue appears to be normal $(\times 200)$

Fig. 2. Frozen section of pancreas biopsy specimen from patient no.2, stained with haematoxylin and eosin. An accumulation of mononuclear cells is seen among exocrine cells. Immunohistochemi-

cal examination of this area revealed many leucocyte common antigen-positive cells but failed to detect any pancreatic hormonepositive cells (photographs not shown), suggesting that this is not insulitis but pancreatitis $(\times 200)$

Fig. 3a and b. Serial frozen sections of biopsy specimen from patient no. 6, stained for insulin (Panel a) and glucagon (Panel b). This islet with elongated shape has no insulin-containing cells and $70-80 \%$ of the cells within this islet are glucagon-positive. Many islets in the biopsy specimens had such a proportion of islet cells $(\times 200)$

rect immunofluorescence method using human type- 0 pancreas as substrate. The amount of C-peptide (CPR) in their urine for $24 \mathrm{~h}$ was $10-25 \mu \mathrm{g} /$ day on most occasions (normal range, 45-115) except patient no. 5 , whose urinary CPR excretion was less than $4 \mu \mathrm{g} / \mathrm{day}$ at any time of the test. The HLA analysis showed that the patients all had DR4. No DR3 was found, as expected, for this phenotype is virtually absent in Japanese people. No significant rise in the titre of antibodies against various "Type 1 diabetes-related" viruses, including coxsackie B4, rubella, mumps, and Epstein-Barr, was observed at the time of diagnosis or thereafter. An elevated percentage of $\mathrm{Ia}^{+}-\mathrm{T}$ or activated-T cells was seen in the peripheral blood lymphocytes of patient nos. 1 and 4.

Control pancreas tissues were obtained from the normal part of the pancreas of patients who underwent pancreatectomy after the diagnosis of pancreas head cancer. The pancreas tissues were treated in the same manner as biopsy specimens.

\section{Pancreas biopsy}

When there was no sign of clotting disorder in the patients, the pancreas biopsy test was done 2 to 4 months after the onset of diabetic symptoms. Air, 1.5 to 2.0 litres, was administered into the abdominal cavity and maintained throughout the procedure. Laparoscopy was carried out by a standard technique using a laparoscope (Olympus, Tokyo, Japan) under local anaesthesia. The trocar puncture site was 2 finger breadths to the left of and 4 finger breadths above the umbilicus. In slender patients like the Type 1 diabetics in this study, the body of the pancreas could be observed easily between the lower edge of the left hepatic lobe and the lesser curvature of the stomach. After inspection of the pancreas, the head end of the operating table was raised to about $30^{\circ}$ and the lesser omentum under the left lobe of the liver was exposed as much as possible. The left hepatic lobe was then elevated by a sound (bougie). When there were few intra- 

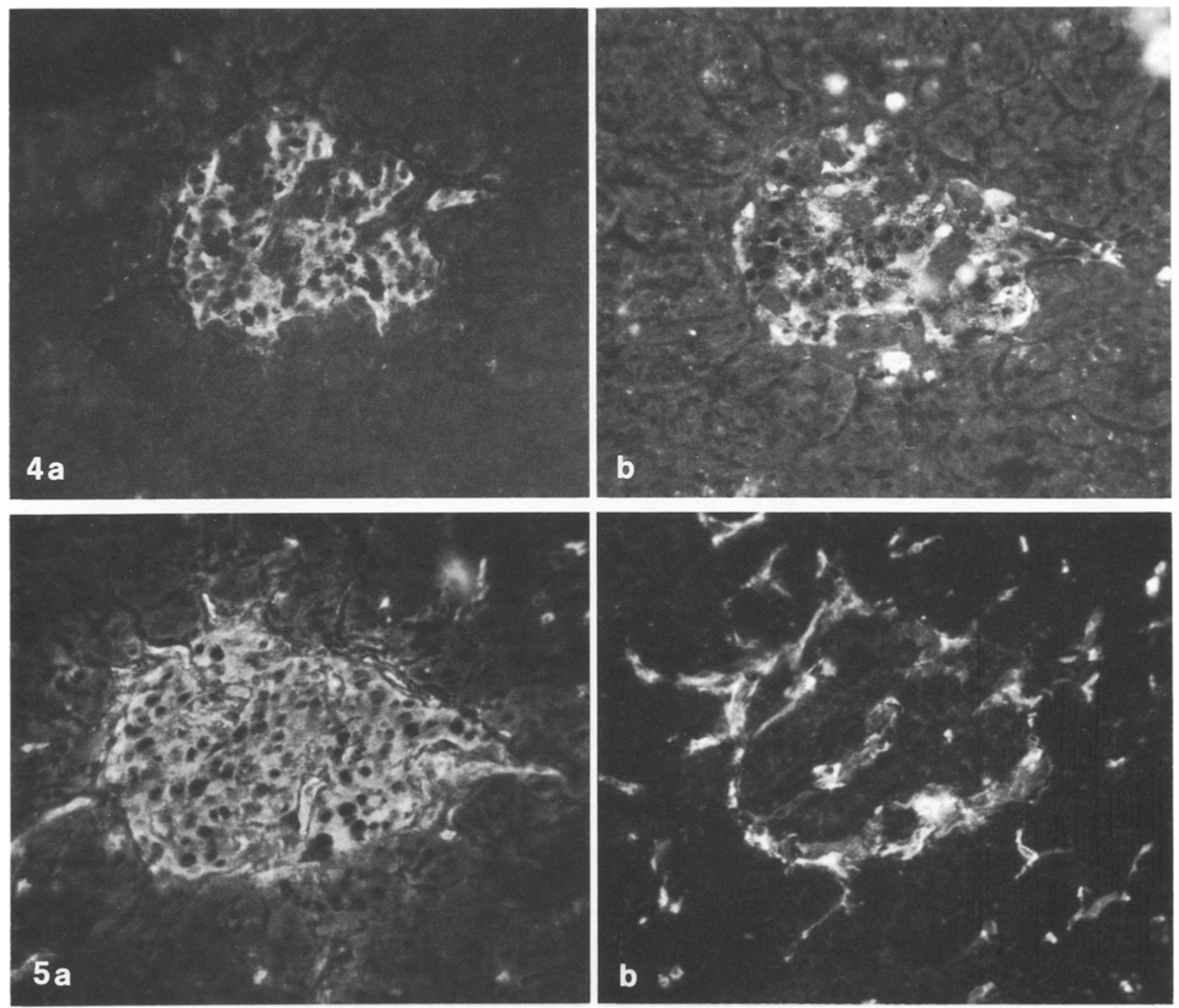

Fig. 4 a and b. Serial frozen sections of a pancreatic biopsy specimen from patient no.4, stained for insulin (Panel a) and glucagon (Panel b). This islet contains a relatively normal proportion of insulin-containing cells and glucagon-containing cells. The islets showing this type of cell composition are rare. Most of the other islets looked like Figure $3(\times 200)$

Fig. 5 a and $\mathbf{b}$. Serial frozen sections of a pancreatic biopsy specimen from patient no. 4, stained for HLA-A,B,C (Panel a) and HLA-DR (Panel b). These two sections were next to those shown in Figure 4. HLA-A,B,C antigen hyperexpression is found in virtually all islet cells as well as in endothelial cells within and around the islet, while HLA-DR antigen hyperexpression is found only in endothelial cells and is not seen in islet cells. Most islets of patient nos. 1,2, 4 and 6 showed this type of HLA staining $(\times 200)$

abdominal fat deposits, which was usually the case in Type 1 diabetic patients at diagnosis, the body of the pancreas could be observed through the transparent lesser omentum.

A biopsy forceps (Olympus) was then inserted into the peritoneal cavity from the left upper quadrant of the abdomen. After the fatty part of lesser omentum was moved aside, the body of the pancreas was punched through the thin membrane of the lesser omentum. Special attention was paid not to injure any visible vessels. After the biopsy, the punched site of the pancreas was carefully examined for at least 10 min until we were certain of no further bleeding. The biopsy was then completed after confirmation of haemostasis by thorough inspection of the peritoneal cavity as well as the biopsy site. Inhibitor of pancreatic enzymes (gabexate mesilate, FOY, Ono Pharmaceutical Company Ltd, Tokyo, Japan) was prophylactically infused for $24 \mathrm{~h}$ after the biopsy, at which time serum amylase and lipase levels were measured every $6 \mathrm{~h}$.

\section{Histological and immunohistochemical examination}

The biopsy specimens were snap frozen at $-70^{\circ} \mathrm{C}$ in isopenthane with dry-ice and acetone. Five $\mu \mathrm{m}$ frozen sections were cut with a cryostat and stained with haematoxylin and eosin (H-E).

The sections were also stained for the immunohistochemical study. They were pre-fixed for $10 \mathrm{~min}$ with acetone. For the detection of pancreatic hormones, the sections were incubated overnight at $4^{\circ} \mathrm{C}$ with guinea pig anti-insulin antibody (JIMRO, Gumma, Japan) diluted 1:200, rabbit anti-glucagon antibody (donated by Dr. S. Iwasa, Takeda Pharmaceutical, Osaka, Japan) diluted 1:200, rabbit anti-somatostatin antibody (Miles Laboratories, Elkhart, Ind., USA) diluted 1:100, or rabbit anti-human pancreatic polypeptide antibody (donated by Dr. R. E. Chance, Eli Lilly and Company, Indianapolis, Ind., USA) diluted 1:100. After washing for $15 \mathrm{~min}$ with phosphate-buffered saline, the sections were further incubated for 
Table 1. Clinical features and immunohistochemical findings of the pancreas biopsy specimens from newly diagnosed Type 1 (insulin-dependent) diabetic patients

\begin{tabular}{|c|c|c|c|c|c|c|c|c|c|c|c|c|c|c|c|c|c|c|c|c|}
\hline \multirow{3}{*}{ Patients } & \multirow{3}{*}{$\begin{array}{l}\text { Age/ } \\
\text { sex }\end{array}$} & \multirow[t]{3}{*}{ Diagnosis } & \multirow{3}{*}{$\begin{array}{l}\text { Dura- } \\
\text { tion of } \\
\text { Dia- } \\
\text { betes } \\
\text { (months) }\end{array}$} & \multirow{3}{*}{$\begin{array}{l}\text { Urine } \\
\text { CPR } \\
(\mu \mathrm{g} / \mathrm{d})\end{array}$} & \multirow[t]{3}{*}{ ICA } & \multirow{3}{*}{$\begin{array}{l}\text { TGHA } \\
\text { MCHA } \\
\text { Other } \\
\text { Abs }\end{array}$} & \multirow[t]{3}{*}{ HLA } & \multirow{3}{*}{$\begin{array}{l}\mathrm{Ia}^{+} \\
\mathrm{T}-\text { cell } \\
(\%)\end{array}$} & \multirow{3}{*}{$\begin{array}{l}\text { Insulin } \\
\text { Dose } \\
\text { (U/d) } \\
\text { at } \\
\text { Biopsy }\end{array}$} & \multicolumn{2}{|l|}{$\mathrm{HE}$} & \multicolumn{9}{|c|}{ Immunohistochemistry ${ }^{\mathrm{a}, \mathrm{b}}$} \\
\hline & & & & & & & & & & \multirow{2}{*}{$\begin{array}{l}\text { Insu- } \\
\text { litis }\end{array}$} & \multirow{2}{*}{$\begin{array}{l}\text { Pan- } \\
\text { crea- } \\
\text { titis }\end{array}$} & \multicolumn{7}{|c|}{ Islet cells } & \multicolumn{2}{|c|}{ Endothelium } \\
\hline & & & & & & & & & & & & Insulin & $\begin{array}{l}\text { Gluca- } \\
\text { gon }\end{array}$ & Somato & $\mathrm{PP}$ & $\mathrm{Ig}$ & $\mathrm{ABC}$ & $\overline{D R}$ & $\mathrm{ABC}$ & $\mathrm{DR}$ \\
\hline 1. K.F. & $33 / \mathrm{M}$ & $\begin{array}{l}\text { Type } 1 \\
\text { diabetes }\end{array}$ & 4 & $6 \sim 15$ & + & $\begin{array}{l}- \\
- \\
-\end{array}$ & $\begin{array}{l}\text { A2,24 } \\
\text { Bw54, w59 } \\
\text { Cw1 } \\
\text { DR4, w8 } \\
\text { DQw1, wa }\end{array}$ & 14 & 8 & - & - & $-\sim+$ & $\pm \sim++$ & \pm & - & - & $+\sim++$ & $\begin{array}{l}\alpha- \\
\beta+\end{array}$ & $+\sim++$ & $+\sim++$ \\
\hline 2. K.T. & $29 / \mathrm{F}$ & $\begin{array}{l}\text { Type } 1 \\
\text { diabetes } \\
\text { Graves' } \\
\text { Sec. } \\
\text { Amenor. }\end{array}$ & 4 & $13 \sim 24$ & + & $\begin{array}{l}2^{6} \times 100 \\
2^{10} \times 100 \\
\text { PCA10 }\end{array}$ & $\begin{array}{l}\text { A2, 24 } \\
\text { B13, w54 } \\
\text { Cw2, w3 } \\
\text { DR4, w9 } \\
\text { DRw53 } \\
\text { DQw3 }\end{array}$ & 0 & 6 & - & + & - & $-\sim++$ & - & - & - & $+\sim++$ & - & $+\sim++$ & $+\sim++$ \\
\hline 3. Y.I. & $25 / \mathrm{F}$ & $\begin{array}{l}\text { Type } 1 \\
\text { diabetes } \\
\text { Sec. } \\
\text { Amenor. }\end{array}$ & 3 & $19 \sim 27$ & + & $\begin{array}{l}- \\
2^{2} \times 100 \\
\mathrm{ANF} 10^{3}\end{array}$ & $\begin{array}{l}\text { A24,- } \\
\text { Bw54,- } \\
\text { Cw1,- } \\
\text { DR4, w6 } \\
\text { DRw52,53 } \\
\text { DQw1,3 }\end{array}$ & 0 & 22 & - & - & - & $-\sim+$ & - & - & - & $-\sim \pm$ & - & + & \pm \\
\hline 4. Y.M. & $26 / \mathrm{M}$ & $\begin{array}{l}\text { Type } 1 \\
\text { diabetes }\end{array}$ & 4 & $7 \sim 19$ & + & $\begin{array}{l}2^{2} \times 100 \\
\mathrm{ANF2}{ }^{1}\end{array}$ & $\begin{array}{l}\text { A24,26 } \\
\text { B40, w62 } \\
\text { Cw3.1,w4 } \\
\text { DR4,w9 } \\
\text { DRw52, } 53 \\
\text { DQw3 }\end{array}$ & 11 & 38 & - & - & $-\sim+$ & + & - & - & - & $+\sim+t$ & - & $+\sim++$ & $+\sim++$ \\
\hline 5. H.K. & $42 / \mathrm{M}$ & $\begin{array}{l}\text { Type } 1 \\
\text { diabetes }\end{array}$ & 3 & $1 \sim 4$ & - & $\begin{array}{l}- \\
- \\
-\end{array}$ & $\begin{array}{l}\text { A24,-- } \\
\text { B44, 54 } \\
\text { C1,-- } \\
\text { DR4, } 14 \\
\text { DRw52, } 53 \\
\text { DQw1, 3 }\end{array}$ & , & 26 & - & - & - & + & \pm & - & - & \pm & - & + & \pm \\
\hline 6. M.K. & $49 / \mathrm{F}$ & $\begin{array}{l}\text { Type } 1 \\
\text { diabetes }\end{array}$ & 2 & $13 \sim 21$ & + & $\begin{array}{l}2^{4} \times 100 \\
2^{10} \times 100\end{array}$ & $\begin{array}{l}\text { A2, 24 } \\
\text { B35,54 } \\
\text { C1,- } \\
\text { DR4,-- } \\
\text { DRw53 } \\
\text { DQw3 }\end{array}$ & 1 & 22 & - & - & $-\sim \pm$ & $+\sim+$ & + & - & - & $+\sim++$ & - & $+\sim++$ & $+\sim++$ \\
\hline 7. K.K. & $24 / \mathrm{M}$ & $\begin{array}{l}\text { Type } 1 \\
\text { diabetes }\end{array}$ & 3 & $8 \sim 27$ & - & $\begin{array}{l}- \\
- \\
-\end{array}$ & $\begin{array}{l}\text { A2, 24 } \\
\text { B54,- } \\
\text { C1,-- } \\
\text { DR4,-- } \\
\text { DRw53,- } \\
\text { DQw3, - }\end{array}$ & 0 & 6 & - & - & $\pm \sim+$ & $+\sim++$ & $+\sim++$ & - & - & $-\sim \pm$ & - & \pm &. \pm \\
\hline $\begin{array}{l}\text { Normal } \\
\text { control } \\
\text { subjects }\end{array}$ & & & & $45-115$ & & & & $<5$ & & - & - & + & + & $\pm \sim+$ & - & - & $-\sim \pm$ & - & $\pm \sim+$ & \pm \\
\hline $\begin{array}{l}\text { Graves } \\
\text { TGHA } \\
\text { tal Cell } \\
\text { ABC }= \\
\text { Scori } \\
++, \geq \\
\text { a }\end{array}$ & $\begin{array}{l}\mathrm{S}^{\prime}=\mathrm{G} \\
\mathrm{A}=\mathrm{Th} \\
1 \mathrm{Anti} \\
=\mathrm{HL} \\
\text { ing sy } \\
\geqq 50 \%\end{array}$ & $\begin{array}{l}\text { raves' Di } \\
\text { lyroglobu } \\
\text { body; } \mathrm{AN} \\
\mathrm{A}-\mathrm{A}, \mathrm{B}, \mathrm{C} \text { a } \\
\text { istem for } \\
\text { positive }\end{array}$ & $\begin{array}{l}\text { isease; } \\
\text { lin Anti } \\
\text { JF = Ant } \\
\text { antigens } \\
\text { the ho } \\
\text { cells; }\end{array}$ & $\begin{array}{l}\text { Sec. A } \\
\text { body H } \\
\text { i-nucle } \\
\text {; DR = } \\
\text { rmone }\end{array}$ & $\begin{array}{l}\text { HLA } \\
\text { stair }\end{array}$ & $\begin{array}{l}\text { or. }=\text { Sec } \\
\text { agglutin } \\
\text { actor; H } \\
\text { A-DR an } \\
\text { ning: - }\end{array}$ & $\begin{array}{l}\text { condary } A \\
\text { nation Tes } \\
E=\text { Haem } \\
\text { ntigens; E1 } \\
\text {, no posi }\end{array}$ & $\begin{array}{l}\text { Amen } \\
\text { st; MC } \\
\text { natoxy } \\
\text { indoth } \\
\text { itive }\end{array}$ & $\begin{array}{l}\text { HA }=1 \\
\text { lin and } \\
\text { elium }= \\
\text { ell; } \pm \text {, }\end{array}$ & $\begin{array}{l}\text { CPl } \\
\text { Micros } \\
\text { Eosin } \\
\text { Endo } \\
<10^{\circ}\end{array}$ & pos & $\begin{array}{l}\text { eptide } \\
\text { ntibod } \\
\text { g; Som } \\
\text { Cells w } \\
\text { ive ce }\end{array}$ & $\begin{array}{l}\text { Immun } \\
y \text { Haem } \\
\text { ato = So } \\
\text { ithin or } \\
\text { ls in the }\end{array}$ & $\begin{array}{l}\text { oreacti } \\
\text { aggluti } \\
\text { natost } \\
\text { around } \\
\text { islets } \\
\text { acitive }\end{array}$ & $\begin{array}{l}\text { vity; } \\
\text { natic } \\
\text { atin; } \\
\text { the } \\
;+\end{array}$ & & $\begin{array}{l}\mathrm{A}=\mathrm{Is} \\
\text { Test; } \mathrm{PC} \\
=\mathrm{Panc} \\
\mathrm{ts} . \\
0 \% \leqq \mathrm{po}\end{array}$ & $\begin{array}{l}\text { let } \\
\text { CA } \\
\text { creat } \\
\text { ositi }\end{array}$ & $\begin{array}{l}\text { ll Anti } \\
\text { Gastric } \\
\text { Polype } \\
\text { cells < }\end{array}$ & $\begin{array}{l}\text { ibody; } \\
\text { Parie- } \\
\text { ptide; } \\
50 \%\end{array}$ \\
\hline
\end{tabular}

$1 \mathrm{~h}$ at room temperature with either fluorescein-isothiocianate (FITC)-conjugated goat anti-guinea-pig IgG (Cappel Laboratories, Cochranville, Pa., USA) diluted 1:40 or FITC-conjugated goat antirabbit IgG (Cooper Biomedical, Inc., Malvern, Pa., USA) diluted 1:40. In the double staining method, rhodamine-conjugated rabbit anti-guinea-pig Igs (Zymed Laboratories Inc., San Francisco, Calif., USA) and Texas Red-conjugated donkey anti-rabbit Igs (Amersham International, Amersham, Bucks, UK) were applied on the sections which had been stained beforehand for HLA antigens. To detect Ig-positive cells, FITC-conjugated rabbit anti-human Ig (Cappel) diluted 1:50 was applied to the sections overnight at $4^{\circ} \mathrm{C}$. Monoclonal mouse anti-human leucocyte common antigen (LCA) (DAKO, Glostrup, Denmark) diluted 1:10 was used as the first antibody for the detection of leucocytes. Scoring system for the hormone staining is as follows: - , no positive cell;,$\pm<10 \%$ positive cells in the islets;,$+ 10 \% \leqq$ positive cells $<50 \% ;++, \geqq 50 \%$ positive cells.

The MHC class I antigen was detected by an incubation of the sections overnight at $4{ }^{\circ} \mathrm{C}$ with mouse monocional anti-MHC class I molecules (Cappel) followed by another incubation for $1 \mathrm{~h}$ at room temperature with FITC-conjugated goat anti-mouse IgG (Cappel) diluted 1:40. As for MHC class II antigens, biotinylated monoclonal antibodies against HLA-DR antigens (Becton-Dickinson, Mountain View, Calif., USA) diluted 1:10 or against DQ molecules (Becton-Dickinson) diluted 1:10 was applied to the sections overnight at $4^{\circ} \mathrm{C}$, followed by another incubation for $1 \mathrm{~h}$ at room temperature with FITC-conjugated avidin (Vector Lab. Inc., Burlingame, Calif., USA) diluted 1:320. The scoring system for the MHC expression is as follows: - , negative; \pm , weakly positive; + , positive; ++ , strongly positive. 
Our criteria for the remaining insulin-secreting capacity are urinary CPR $>10 \mu \mathrm{g} /$ day and/or the presence of insulin-containing cells in the biopsy specimen. Our criteria for the involvement of active autoimmune phenomena against beta-cells are (1) presence of ICA, (2) insulitis and (3) Ig deposition in islet cells. Our criteria for "possibly autoimmune-related phenomena" are (4) ectopic expression of class II MHC antigen in beta-cells and (5) hyperexpression of class I $\mathrm{MHC}$ antigen in islet cells.

\section{Results \\ Pancreas biopsy}

Pancreas biopsy was done without any serious complications in all patients. Pain was easily controlled with premedication of sedatives and local anaesthesia. Pancreas could be seen between the frontal edge of the liver and the lesser curvature of the stomach. Two to three specimens were obtained from the body of the pancreas. The size of each specimen was about $2-5 \mathrm{~mm}$ long and the weight was 20-30 $\mathrm{mg}$. The estimated blood loss was about $1 \mathrm{ml}$. There were no complications such as intractable bleeding of more than $2 \mathrm{ml}$, leakage of pancreatic juice, pancreatitis, or peritonitis. Neither serum amylase nor lipase levels were elevated after the biopsy.

\section{H-E staining}

Pancreatic islets were detected in all patients. The number of islets seen in each specimen ranged from two to ten. Most of the islets were small and appeared atrophic (Fig. 1). They often seemed distorted. Lymphocytic infiltration within or around the islets was hardly seen in any specimens examined. However, a focus of lymphocyte cluster was detected in one area of the specimen from patient no. 2 (Fig.2). No endocrine-like cell was observed in this area. Acinar cells seemed to be normal in all patients.

\section{Immunohistochemical study}

The results of immunohistochemical study are shown in Table 1. Anti-insulin staining showed that there were no remaining insulin-containing cells in the islets of the specimens from patient nos.2, 3, and 5 (Fig. 3a). Specimens from the other four patients (nos. 1, 4, 6, and 7) had some islets containing residual insulin cells (Fig. 4 a). The number of insulin-containing cells were small in all four cases, although a few islets appeared to have a normal proportion of beta-cells.

Glucagon-containing cells, on the other hand, were well preserved in all 7 cases (Fig. 4b). In some insulin-deficient islets, more than $50 \%$ of the cells were glucagon positive (Fig. 3 b). Somatostatin-positive cells were detected in the specimens from patient nos. 1, 5, 6, and 7. Patient no. 7 had an islet abundant in somatostatin. As for pancreatic polypeptide (PP) staining, PP-containing cells were not observed in any specimens, probably because the biopsy specimens had not been obtained from the PP-rich lobe, which is located at the dorsal part of the
Table 2. Summary of immunohistochemical examination of the pancreas biopsy specimens from newly diagnosed Type 1 (insulindependent) diabetic patients

\begin{tabular}{lc}
\hline 1. Islets: decreased number and/or atrophic shape & $7 / 7$ \\
2. Mononuclear cell infiltration to the islets & $0 / 7$ \\
3. Deposition of immunoglobulins to the islets & $0 / 7$ \\
4. Beta-cells remained & $4 / 7$ \\
5. Alpha-cells remained & $7 / 7$ \\
6. HLA-A,B,C increased in islet cells & $4 / 7$ \\
7. HLA-A,B,Cincreased in endothelium & $4 / 7$ \\
8. HLA-DR expressed in beta-cells & $1 / 7$ \\
& $\left(1 / 4^{\mathrm{a}}\right)$ \\
9. HLA-DR increased in endothelium & $4 / 7$ \\
\hline
\end{tabular}

${ }^{a}$ When only four patients who have remaining beta-cells are taken into account

pancreas head. Deposition of Ig in islet cells could not be detected in any patients. Anti-LCA staining did not show any leucocytes within or around the islets. The only positive staining with anti-LCA was observed in the non-islet area, where lymphocytes were seen accumulated with $\mathrm{H}-\mathrm{E}$ staining in patient no.2. While this immunohistochemical study did not confirm the presence of leucocytes within or around the islets, a few lymphocytes were occasionally detected in the islets by electron microscopical examination performed in parallel with this study (data not shown).

The staining for MHC class I (HLA-A,B,C) antigens showed that these antigens were hyperexpressed in islet cells and in the vascular endothelium within and around the islets in four patients (nos. 1,2,4, and 6) (Fig. 5a) when compared to the control pancreases. The double staining for class I and insulin revealed that insulin-positive cells had hyperexpression of class I molecules in three patients (nos. 1, 4, and 6) whose beta-cells remained. Hyperexpression of class I antigen was also found in glucagon-positive cells in all four patients (nos. 1, 2, 4 and 6). Somatostatinpositive cells in patient nos. 1 and 6 were also positive for class I. HLA-A,B,C antigen expression in endothelial cells in the exocrine pancreatic tissue appeared to be normal in all patients.

The expression of MHC class II antigens (both DR and DQ) was increased in the endothelial cells within and around the islets in four patients (nos.1,2, 4, and 6) (Fig. 5b). These same four patients also showed the hyperexpression of class I molecules as described above. The ectopic expression of class II antigens in the islet cells was seen in one patient (no.1) (Fig. 6a). The double staining for class II antigens and insulin showed that insulin-containing cells were also positive for class II molecules (Fig. 6a and b). When the double staining for class II molecules and glucagon was carried out in the same islet of a serial section of Figure 6, glucagon-positive cells were negative for class II antigens (Fig. $7 \mathrm{a}$ and $\mathrm{b}$ ). These results indicate that HLA-DR antigens were expressed in beta cells but not in alpha-cells. The summary of histological and immunohistochemical findings is shown in Table 2. 

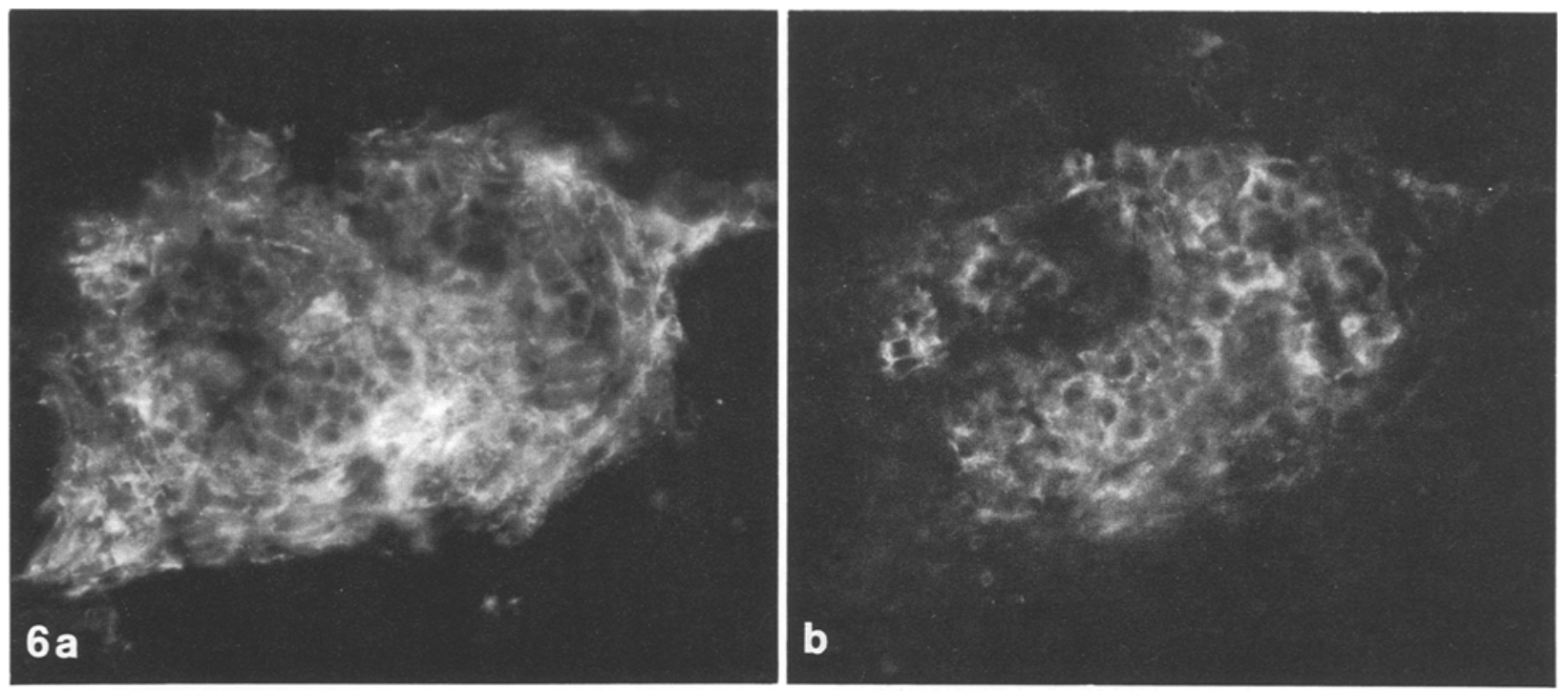

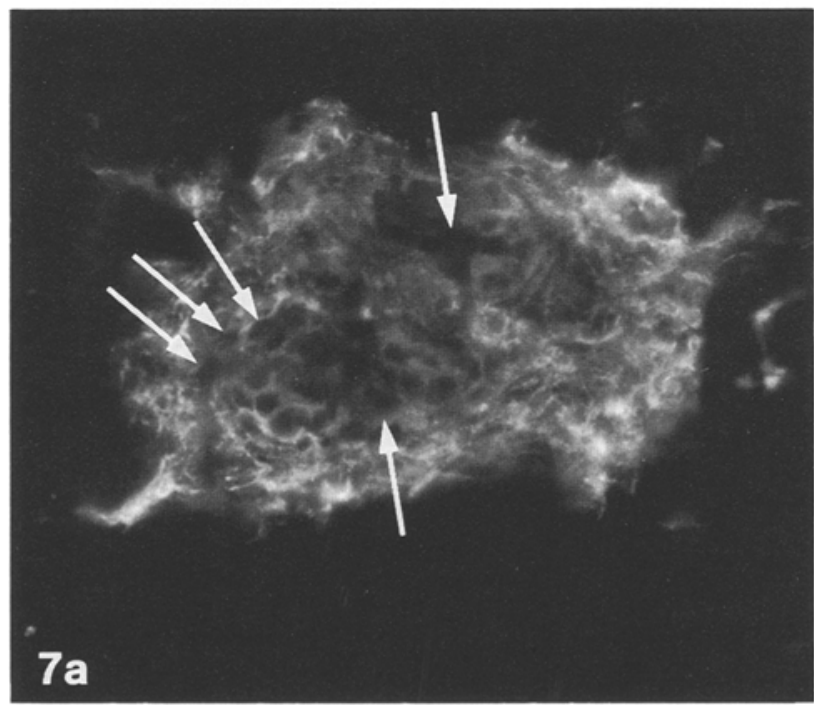

Fig. 6a and b. Double staining for HLA-DR (Panel a) and insulin (Panel b) of a frozen section from patient no. 1. Most, but not all, islet cells as well as endothelial cells in this islet are strongly positive for HLA-DR (a). Endothelial cells surrounding this islet show stronger DR expression than islet cells. Counterstaining of the same section for insulin (b) reveals that virtually all insulin-containing cells are HLA-DR-positive. Two islets in the biopsy specimen from patient no. 1 showed this HLA-DR expression, while no other patients examined in this study had such islets in the biopsy specimens $(\times 300)$

\section{Discussion}

Several studies have reported on the pathological findings of islets in Type 1 diabetic patients [3-7]. However, all the studies so far have been made on autopsy samples of the patients. This study has shown for the first time immunohistochemical features of pancreas biopsy specimens obtained from newly diagnosed Type 1 diabetic patients. The safety of the method for pancreas biopsy has already been established $[8,9]$. Our study further confirmed that pancreas biopsy under laparoscopy could be performed safely by skilled doctors without any complication.

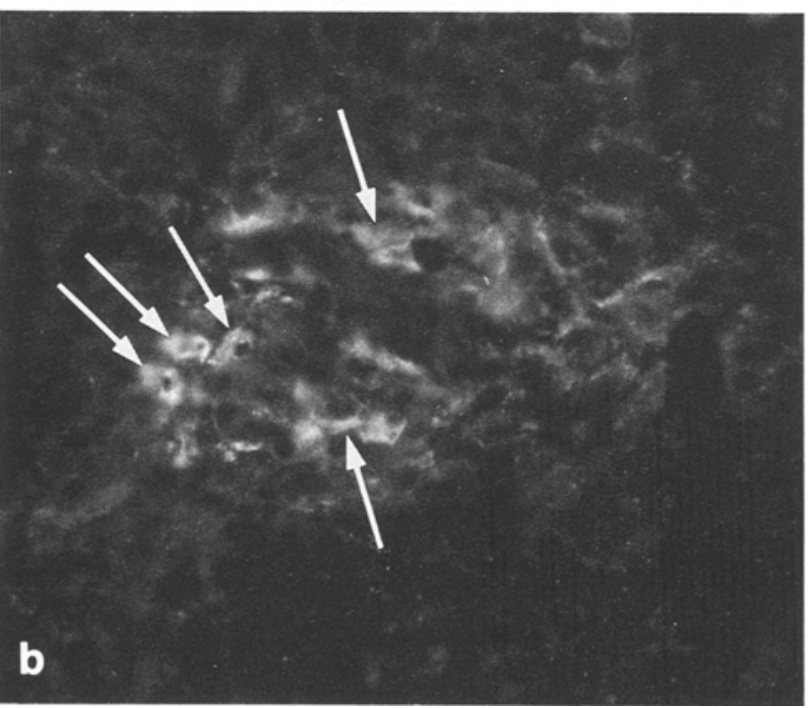

Fig. 7a and b. Double staining for HLA-DR (Panel a) and glucagon (Panel b) of a frozen section from patient 1 . This section was next to that shown in Figure 6. More than half of the endocrine cells and endothelial cells surrounding the islet express HLA-DR antigens, while some cells inside this islet are negative for DR (a). Counterstaining of the same section for glucagon (b) reveals that glucagonpositive cells are HLA-DR-negative (arrows). This result together with that shown in Figure 6 indicates that HLA-DR antigens are expressed in insulin-containing beta-cells but not in glucagon-containing alpha-cells $(\times 300)$

An unexpected finding was the absence of insulitis or mononuclear cell infiltration in the islets, although electron microscopical study performed in parallel with light microscopical examination revealed a few lymphocytes in the islets (data not shown). Previous reports in autopsy samples suggest that insulitis is found in insulin-containing islets and is virtually absent in insulin-deficient islets [6]. Several possibilities may be considered for the absence of mononuclear cell infiltration to islets in our study: the size of the specimen was too small, the number of insulin-containing islets was too limited, the time of biopsy was too late, or Japanese Type 1 diabetic patients are dif- 
ferent from Caucasian patients. In view of the heterogeneity of islet histopathology in Type 1 diabetic patients [3, $6,10,11]$, sampling errors could occur and it is possible that other areas of the pancreas contained islets with lymphocytic infiltration. However, it was both technically and ethically impossible to get specimens from all areas of the pancreas. The absence of insulitis in the islets examined may be partly because the biopsy was done too late. Immunosuppressive therapy with cyclosporine has been reported to be more effective in patients with less than 30 days of diabetic symptoms than in patients with treatment started after 30 days [12]. This fact suggests that the autoimmune phenomena which destroy beta-cells subside by the second month of the disease, and the 2 to 4 months after the diagnosis when we performed the pancreas biopsy in our patients appears to be too late to directly detect these autoimmune phenomena. Thus, this problem may be overcome by performing the biopsy in an earlier stage of the disease.

Interestingly, although the direct evidence for autoimmune phenomena could not be detected, several "possibly autoimmune-related findings" were seen in the islets of some patients. The findings include the hyperexpression of MHC class I molecules both in islet cells and in endothelial cells within and around the islets, hyperexpression of MHC class II molecules in endothelium within and around the islets, and the ectopic expression of class II antigen in insulin-containing beta-cells. The implication of these findings still remains to be elucidated [7, 10, 11]. In view of the hypothesis by Bottazzo et al. for the initiation and progression of organ-specific autoimmune diseases, MHC antigens in islet cells and insular endothelium may well be involved in the destruction of beta-cells followed by the development of Type 1 diabetes [13, 14].

With regard to the participation of viruses in the pathogenesis of beta-cell destruction, the patients in this study did not show any significant rise in the titre of antibodies against "Type 1 diabetes-related" viruses [15]. Electron microscopical examination carried out in parallel with this immunohistochemical study also failed to show any viral particles in the biopsy specimens. Thus, the direct involvement of viruses is unlikely in our Type 1 diabetic patients, although the possibility still remains that the insidious viral infection to beta-cells either initiated a chain of autoimmune reactions against beta-cells or participated in the further degradation of these cells.

In summary, pancreas biopsy under laparoscopy was performed safely without any complication in seven newly diagnosed Type 1 diabetic patients. Immunohistochemical analysis of the biopsy specimens revealed many abnormalities in hormone content and MHC antigen expression. We conclude that pancreas biopsy under laparoscopy reveals various phenomena occurring in the islets of newly diagnosed Type 1 diabetic patients. However, despite our original intention, since pancreas biopsy failed to detect insulitis or Ig deposition partly because of sampling errors, this study also indicates that pancreas biopsy may not be suitable under the present protocol for the selection of patients for immunotherapy. Improvements are necessary when using immunohistochemical observations for this purpose.
Acknowledgements. We would like to thank Dr. M.Sada (National Cardiovascular Center, Osaka, Japan) for performing HLA-typing of the patients, Dr. S. Iwasa, (Takeda Pharmaceutical, Osaka, Japan) for providing us with anti-glucagon antibody, Dr. R. E. Chance (Eli Lilly and Company, Indianapolis, Ind., USA) for providing us with anti-pancreatic polypeptide serum. This work was supported in part by the Scientific Research Fund from the Ministry of Education Science and Culture of Japan and grants from the Japan Insulin Study Group and Tsujino Foundation.

\section{References}

1. Eisenbarth GS (1986) Type I diabetes mellitus, a chronic autoimmune disease. N Engl J Med 314: 1360-1368

2. Bottazzo GF (1984) $\beta$-cell damage in diabetic insulitis: are we approaching a solution? Diabetologia 26: 241-249

3. Gepts W (1965) Pathological anatomy of the pancreas in juvenile diabetes. Diabetes 14: 619-633

4. Junker K, Egeberg J, Kromann H, Nerup J (1977) An autopsy study of the islets of Langerhans in acute-onset juvenile diabetes mellitus. Acta Pathol Microbiol Scand Sect A 85: 699-706

5. Doniach I, Morgan AG (1973) Islets of Langerhans in juvenile diabetes mellitus. Clin Endocrinol 2: 233-248

6. Foulis AK, Liddle CN, Farquharson MA, Richmond JA, Weir RS (1986) The histopathology of the pancreas in Type 1 (insulin-dependent) diabetes mellitus: a 25-year review of deaths in patients under 20 years of age in the United Kingdom. Diabetologia 29: 267-274

7. Bottazzo GF, Dean BM, McNally JM, MacKay EH, Swift PGF, Gamble DR (1985) In situ characterization of autoimmune phenomena and expression of HLA molecules in the pancreas in diabetic insulitis. N Engl J Med 313: 353-360

8. Meyer-Burg J (1972) The inspection, palpation and biopsy for the pancreas. Endoscopy 4: 99-101

9. Ishida $H$ (1983) Peritoneoscopy and pancreas biopsy in the diagnosis of pancreatic diseases. Gastrointest Endosc 29: 211-218

10. Foulis AK, Farquharson MA (1986) Aberrant expression of HLA-DR antigens by insulin-containing beta-cells in recentonset Type I diabetes mellitus. Diabetes 35: 1215-1224

11. Foulis AK, Farquharson MA, Hardman R (1987) Aberrant expression of Class II major histocompatibility complex molecules by B cells and hyperexpression of Class I major histocompatibility complex molecules by insulin containing islets in Type 1 (insulin-dependent) diabetes mellitus. Diabetologia 30: 333-343

12. Bougneres PF, Carel JC, Castano L, Boitard C, Gardin JP, Landais P, Hors J, Mihatsch MJ, Pillard M, Chaussain JL, Bach JF (1988) Factors associated with early remission of Type I diabetes in children treated with cyclosporine. N Engl J Med 318: 663-670

13. Bottazzo GF, Pujol-Borrell R, Hanafusa T, Feldmann M (1983) Role of aberrant HLA-DR expression and antigen presentation in the induction of endocrine autoimmunity. Lancet II: 11151118

14. Hanafusa T, Pujol-Borrell R, Chiovato L, Russell RCG, Doniach D, Bottazzo GF (1983) Aberrant expression of HLA-DR antigen on thyrocytes in Graves' disease: relevance for autoimmunity. Lancet II: 1111-1115

15. Jenson AB, Rosenberg HS (1984) Multiple viruses in diabetes mellitus. Prog Med Virol 29: 197-217

Received: 14 March 1989

and in final revised form: 10 October 1989

Dr. T. Hanafusa

The Second Department of Internal Medicine

Osaka University Medical School

1-1-50 Fukushima, Fukushima-ku

Osaka 553

Japan 